\title{
Managing for rainfall variability: effect of grazing strategy on cattle production in a dry tropical savanna
}

\author{
Peter O'Reagain ${ }^{\mathrm{A}, \mathrm{C}}$, John Bushell ${ }^{\mathrm{A}}$, Chris Holloway ${ }^{\mathrm{A}}$ and Angela Reid ${ }^{\mathrm{B}}$ \\ ${ }^{A}$ Queensland Department of Primary Industries and Fisheries, PO Box 976, Charters Towers, Qld 4820, Australia. \\ ${ }^{B}$ Queensland Department of Primary Industries and Fisheries, PO Box 1085, Townsville, Qld 4810, Australia. \\ ${ }^{\mathrm{C}}$ Corresponding author. Email: peter.oreagain@dpi.qld.gov.au
}

\begin{abstract}
Rainfall variability is a challenge to sustainable and profitable cattle production in northern Australia. Strategies recommended to manage for rainfall variability, like light or variable stocking, are not widely adopted. This is due partly to the perception that sustainability and profitability are incompatible.

A large, long-term grazing trial was initiated in 1997 in north Queensland, Australia, to test the effect of different grazing strategies on cattle production. These strategies are: (i) constant light stocking (LSR) at long-term carrying capacity (LTCC); (ii) constant heavy stocking (HSR) at twice LTCC; (iii) rotational wet-season spelling (R/Spell) at 1.5 LTCC; (iv) variable stocking (VAR), with stocking rates adjusted in May based on available pasture; and (v) a Southern Oscillation Index (SOI) variable strategy, with stocking rates adjusted in November, based on available pasture and SOI seasonal forecasts.

Animal performance varied markedly over the 10 years for which data is presented, due to pronounced differences in rainfall and pasture availability. Nonetheless, lighter stocking at or about LTCC consistently gave the best individual liveweight gain (LWG), condition score and skeletal growth; mean LWG per annum was thus highest in the LSR (113 kg), intermediate in the R/Spell $(104 \mathrm{~kg}$ ) and lowest in the HSR $(86 \mathrm{~kg})$. Mean LWG was $106 \mathrm{~kg}$ in the VAR and $103 \mathrm{~kg}$ in the SOI but, in all years, the relative performance of these strategies was dependent upon the stocking rate applied. After 2 years on the trial, steers from lightly stocked strategies were 60-100 kg heavier and received appreciable carcass price premiums at the meatworks compared to those under heavy stocking.

In contrast, LWG per unit area was greatest at stocking rates of about twice LTCC; mean LWG/ha was thus greatest in the HSR ( $21 \mathrm{~kg} / \mathrm{ha})$, but this strategy required drought feeding in four of the 10 years and was unsustainable. Although LWG/ha was lower in the LSR (mean $14 \mathrm{~kg} / \mathrm{ha}$ ), or in strategies that reduced stocking rates in dry years like the VAR (mean $18 \mathrm{~kg} / \mathrm{ha}$ ) and SOI (mean $17 \mathrm{~kg} / \mathrm{ha}$ ), these strategies did not require drought feeding and appeared sustainable. The R/Spell strategy (mean $104 \mathrm{~kg} / \mathrm{ha}$ ) was compromised by an ill-timed fire, but also performed satisfactorily.

The present results provide important evidence challenging the assumption that sustainable management in a variable environment is unprofitable. Further research is required to fully quantify the long-term effects of these strategies on land condition and profitability and to extrapolate the results to breeder performance at the property level.
\end{abstract}

Additional keywords: stocking rate, Southern Oscillation Index, pasture spelling.

\section{Introduction}

Inter-annual rainfall variability is a major challenge for sustainable and economic cattle production in the dry tropical savannas of north Queensland. Rainfall variability leads to sharp fluctuations in pasture production and hence short-term carrying capacity between years. Despite this, many properties tend to be set-stocked, overstocked and/or only respond to rainfall variability in a reactive fashion. Consequently, in drier years, fodder demand can often exceed supply, resulting in severe overgrazing of native pastures. In north Queensland this problem has been exacerbated by the introduction of more resilient Bos indicus cattle and improved supplementary feeding (Gardner et al. 1990), which allow grazing pressure to be maintained in even the most severe droughts.

Overstocking in dry years has significant economic consequences for the cattle industry with properties incurring major economic loss through the costs of drought feeding, agistment, lost production and even stock loss. The cooccurrence of drought and overstocking (McKeon et al. 2004) has also led to a significant decline in land and pasture condition in north Queensland in terms of reduced ground cover and a decline in perennial grass species (De Corte et al. 1991; Tothill and Gillies 1992). Declining land condition has major adverse effects upon water quality, which is an issue of major concern for the health of the Great Barrier Reef Lagoon (Furnas 2003).

The issue of rainfall variability has long been recognised as a major challenge to sustainable rangeland management (Wilson and Harrington 1984) and several management strategies have been promoted to manage this issue (Danckwerts et al. 1993). First, light (conservative) stocking aims to utilise some 'safe' amount of forage, usually $\sim 15-25 \%$ of the average annual pasture growth (Johnston et al. 2000) that can be expected to be produced in most (e.g. 70\%) years. Light stocking may have relatively 
lower returns in good rainfall years but in below average years it should out-perform other strategies, due to lower costs and better animal performance (Foran and Stafford-Smith 1991). Importantly, it should also maintain land and pasture condition in a sustainable and productive state.

Second, variable stocking involves matching animal numbers to fodder supply, so as to capitalise on good years. Pasture degradation and economic loss is minimised in dry years through the timely reduction in stocking rates (e.g. Mann 1993). In the highly seasonal environment of northern Australia, the logical time to adjust stock numbers is at the end of the wet season (about May) when stock are at their most marketable and the chances of further rainfall in the next 6 to 9 months are low [Ebersohn 1973 cited by Orr et al. (1993)]. More advanced versions of the variable strategy involve the use of seasonal climate forecasts, like the Southern Oscillation Index, to proactively adjust stock numbers in advance of any short-term rainfall variation (McKeon et al. 1990).

Third, rotational spelling involves resting a set portion of a property each growing season to allow forage to accumulate, to buffer variation in fodder supply and improve pasture composition (Danckwerts et al. 1993). Wet season spelling also appears to ameliorate the effects of increased pasture utilisation rates (up to 50\%) on land condition (Ash et al. 2001).

While the above strategies have been extensively promoted for many years, adoption rates have been disappointing with a significant proportion of managers persisting with the more traditional strategies of heavier stocking, delayed destocking and the use of drought feeding to cope with below-average rainfall years. The reasons for non-adoption are complex but an important factor is the belief that sustainable management is uneconomic and that heavy stocking rates maximise economic return, at least in the short to medium (5-10 years) term (Lawrence et al. 1994; O'Reagain et al. 2003).

The paradigm of 'more cattle equal more money' is difficult to challenge, given the disparate experimental and anecdotal evidence available. The majority of previous grazing trials in Queensland are of limited relevance to the extensive native pastures of the north, either because they involved exotic legumes and/or grasses (Winks et al. 1974; Jones 2003) or were conducted in southern (Shaw and t'Mannetjie 1970; Scattini 1973), central or western Queensland (Roe and Allen 1993).

Possibly the most relevant study is that of Gillard (1979), investigating the effects of stocking rate on animal production on native pastures in north Queensland. However, this work is also of limited applicability given that it only compared two stocking rates and also involved tree killing, exotic legumes and pasture fertilisation. Recent work has clearly demonstrated the benefits of light utilisation (stocking) rates and wet season spelling on native pasture condition in the area (McIvor and Gardner 1995; Ash et al. 2001), but the relative impacts of these practices on animal production and economic performance have yet to be empirically quantified.

Previous grazing trials have also been conducted on relatively small, uniform paddocks ranging from 2 to 30 ha in size (e.g. Jones 2003). Such data are of limited relevance in extensive rangeland areas where paddocks are usually large and contain a diversity of soil and pasture types (Ash and Stafford-Smith 1996). More importantly, the majority of these trials focussed on stocking rate per se and did not explicitly address the issue of managing for rainfall variability in a complex and variable environment.

These issues were partly addressed in four large, onproperty producer demonstration sites in north Queensland (Smith 2000), which investigated the impact of different stocking strategies on breeder performance. Unfortunately, these short-term results were inconclusive and are difficult to interpret because of their lack of replication and the betweenpaddock variability caused by differences in soil type, previous management and fire.

Many graziers have obviously achieved both good economic performance and land condition through a combination of light (Landsberg et al. 1998) or variable stocking (Mann 1993) and/or wet season spelling (Purvis 1986), indicating that good land management and economic performance are not necessarily mutually exclusive. However, case studies such as these are often discounted as anomalies by the wider grazier community due to a range of real or perceived differences in factors such as rainfall, property size, land type, financial position and/or herd genetics.

Many of the recommended grazing strategies for managing rainfall variability have thus not been tested at a scale or in a manner relevant to the beef industry. Accordingly, there is little objective data on their long-term profitability and sustainability relative to existing systems such as constant heavy stocking. As articulated by Stockwell et al. (1991) 'there are few hard data to convince cattlemen that the... overwhelming conventional wisdom that more cattle means more money is not necessarily correct'.

In 1997, a large grazing trial was established in north Queensland with the specific objective of quantifying the relative effects of different grazing strategies on animal production, economic performance and resource condition in a manner and at a scale relevant to commercial properties. This paper presents results from the first 10 years of this ongoing trial on the effects of these grazing strategies on animal production. Data on the impact of these grazing strategies on economic performance, land condition and soil loss are presented elsewhere (O'Reagain et al. 2005, 2007, 2008; O'Reagain and Bushell 2008) and will be published in later papers.

\section{Materials and methods}

\section{Site description}

The trail is located on Wambiana $\left(20^{\circ} 34^{\prime} \mathrm{S}, 146^{\circ} 07^{\prime} \mathrm{E}\right), 70 \mathrm{~km}$ south-west of Charters Towers, north Queensland, Australia. Long-term (98 year) mean annual precipitation for the nearest Bureau of Meteorology rainfall station at Trafalgar, $17 \mathrm{~km}$ northwest of the trial is $636 \mathrm{~mm}(\mathrm{CV}=40 \%)$. Rainfall is generally highly seasonal, with most (70\%) falling between December and March and a long dry season occurring in intervening months (Clewett et al. 2003). Soils are derived from tertiary sediments, are relatively infertile (De Corte et al. 1991) and include kandosols, sodosols, chromosols and vertosols (Isbell 1996). The trial was conducted on these tertiary sediments because of the prevalence of similar, low fertility land types in northern Australia.

The study area is located in the Aristida-Bothriochloa pasture community (Tothill and Gillies 1992) and is an open savanna 
dominated by Eucalyptus, and to a lesser extent, Acacia, woodland species, overlying $\mathrm{C}_{4}$ tropical grasses. The native shrub Carissa ovata is also common on some soils. Cattle have grazed the study area for at least the last 130 years and pastures were in moderate to good condition when the trial started.

\section{Paddock layout}

A detailed soil and vegetation site survey was conducted in early to mid 1997. The geographic information system ArcView (ESRI, Redlands, California, USA) was then used to plan the trial layout and ensure that experimental paddocks contained similar percentages $(\%)$ of the three main soil-vegetation associations (Fig. 1). These associations and their percentage of total paddock area are:

(i) Eucalyptus melanophloia community on Yellow/Red Kandosols (23\%). These relatively well drained, low fertility soils are dominated by unpalatable grasses like Eriachne mucronata and Aristida spp., but may also contain appreciable quantities of Chrysopogon fallax and Heteropogon contortus.

(ii) Acacia harpophylla-Eucalyptus brownii community on Grey Vertosols (22\%). These more fertile areas are largely dominated by Dicanthium sericeum, Bothriochloa ewartiana and Eulalia aurea.

(iii) E. brownii community on Brown Sodosols and Chromosols $(55 \%)$. These soils are relatively shallow $(30-40 \mathrm{~cm})$, of moderate fertility and are commonly dominated by a Chrysopogon fallax - Bothriochloa ewartiana pasture layer.
There are 10 paddocks ranging in size from 93 to 117 ha, laid out in a randomised block design, with two blocks of five treatments (Fig. 1). The resources and finances available precluded greater replication. Each paddock has two watering points so that the maximum distance to water is less than $1.2 \mathrm{~km}$.

\section{Site management}

A grazier advisory committee (GAC) of nine commercial cattle graziers from the local Dalrymple shire was established in September 1997 to advise on treatments, stocking rates and general trial management issues. The aim of the GAC is to maximise the relevance of trial results to the grazing industry, enhance the adoption of project outcomes and stimulate discussion and debate on sustainable and profitable management in a variable environment.

\section{Treatments and stocking rates}

Five grazing strategies were selected for testing, based on one or more of the following reasons. First, the strategy was already practised in the area, such as light (Landsberg et al. 1998), variable (Mann 1993), or heavy stocking. Second, their relative economic, environmental and productive performance over a range of historical rainfall years had been explored in simulation models (Ash et al. 2000; McKeon et al. 2000). Fieldtesting of the strategies would thus inform and validate these models. In turn, these simulation models would possibly allow extrapolation of results to other land types and/or rainfall scenarios (O'Reagain et al. 2003). Third, the strategies were practical management options for a region characterised by large

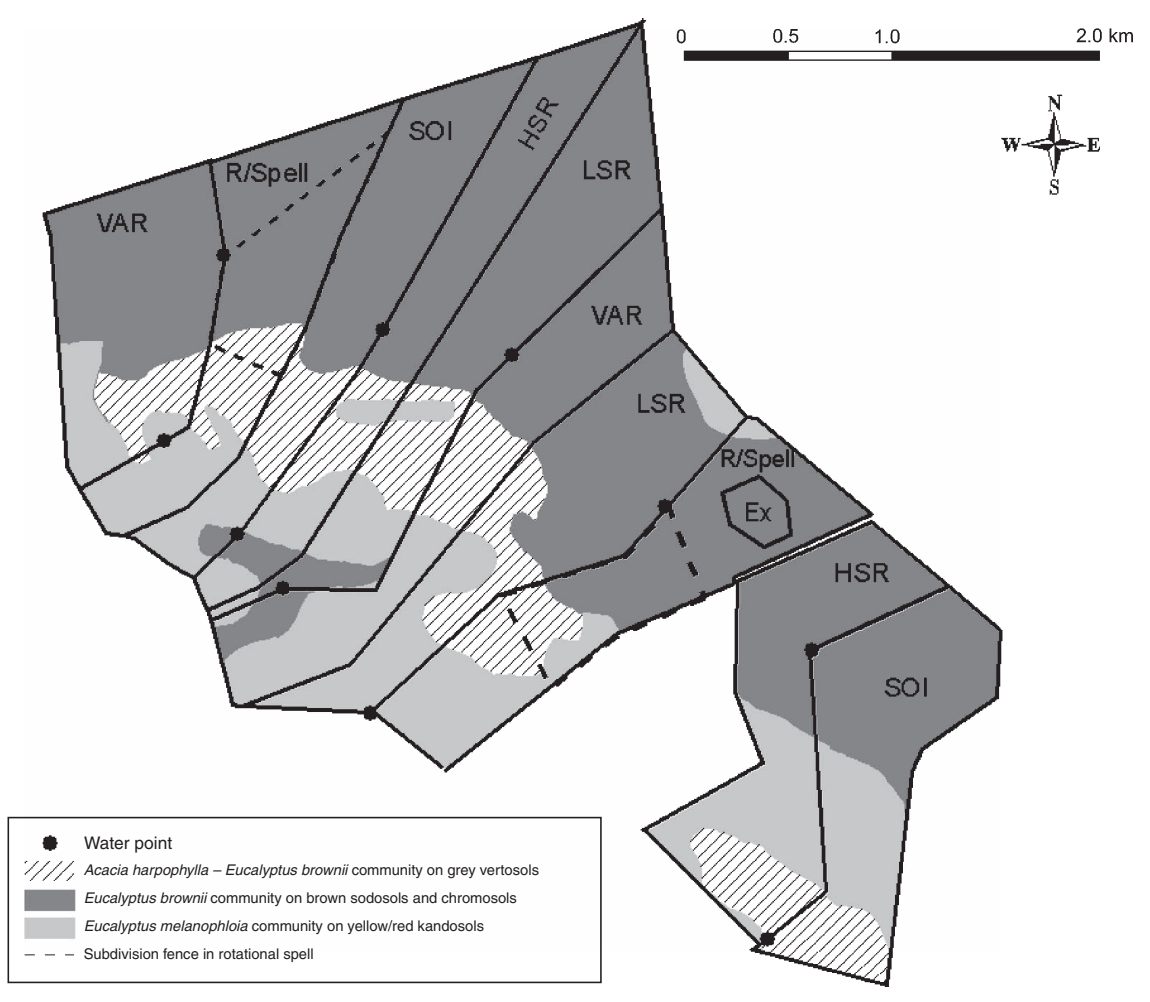

Fig. 1. Layout of treatments, paddocks and watering points across the three major soil-vegetation associations at the Wambiana grazing trial. Ex, grazing exclosure. See text for treatment abbreviations. 
paddock sizes and a relative lack of stock water, fences and labour. Intensive rotational grazing strategies were not considered for testing in the present study, partly due to the latter reason. The available evidence also indicates that stocking rate is a far greater determinant of animal production and pasture condition than grazing system (O'Reagain and Turner 1992).

Long-term sustainable carrying capacity (LTCC) of the site was calculated based on the estimated pasture production potential of the various land types and target pasture utilisation rates, i.e. the percentage (\%) of annual pasture growth utilised by grazing (Chilcott et al. 2003). Research trials, simulation models and property case studies indicate that long-term average sustainable pasture use for native pastures in Queensland is $\sim 20-25 \%$ of annual pasture growth (McKeon et al. 1990). Calculated LTCCs for the different land types were within the range of carrying capacities estimated by the GAC. The actual stocking rates used in the trial (see below) were based on LTCC and target mean annual utilisation rate of $25 \%$ and $50 \%$ for light and heavy stocking, respectively, adjusted according to the advice of the GAC.

Target stocking rates for each paddock in each grazing year (defined as $\sim 1$ June to 31 May the following year) are calculated based on the expected mean mass of steers over the next 12 months, i.e. starting weight + half of its expected weight gain for the coming year (assumed to be $100 \mathrm{~kg}$ in all years). In practice, the actual stocking rates achieved often differ slightly from those planned because of differences between actual and expected weight gains and the practical difficulties of achieving exact stocking rates with large animals in relatively small paddocks.

The trial paddocks were first stocked on 19 December 1997. The grazing strategies being tested and their nominal stocking rates through the years of the trial are as follows.

\section{Light stocking rate}

In strategy 1 (LSR), paddocks are stocked at LTCC to achieve the recommended safe average utilisation rate (20-25\%) of pasture growth that could be expected to be produced in most $(\sim 70 \%)$ years. The LSR was set stocked at $\sim 10$ ha per animal equivalent (AE: defined as a $450 \mathrm{~kg}$ steer) between 1997-98 and 2000-01, and at $\sim 8 \mathrm{ha} / \mathrm{AE}$ thereafter (Table 1).

\section{Heavy stocking rate}

In strategy 2 (HSR), paddocks are stocked at twice the LTCC to achieve an average of $40-50 \%$ utilisation of the pasture growth that could be expected to be produced in most years. The HSR was set stocked at $~ 5 \mathrm{ha} / \mathrm{AE}$ between 1997-98 and 2000-01, and at $\sim 4$ ha/AE thereafter. In May 2005, the stocking rate was cut to $\sim 6 \mathrm{ha} / \mathrm{AE}$ and maintained at this level thereafter because of the scarcity of forage (Fig. 3) and the obvious inability of the HSR paddocks to sustain the original stock numbers for that strategy through the dry season.

\section{Variable stocking rate}

In strategy 3 (VAR), stocking rates are adjusted annually at the end of the wet season (May) as follows: pasture total standing dry matter (TSDM) is determined for each paddock at the end of the wet season in May as described below. Available forage is calculated by discounting pasture TSDM for wastage $(\sim 50 \%)$ as well as a minimum residue $(500-800 \mathrm{~kg} / \mathrm{ha})$ to prevent soil erosion. The stocking rate for the next 12 months is then calculated from the total available forage per paddock divided by the estimated DM requirement per AE per annum (taken as $1.5 \%$ of body mass per day). Note that this method takes no account of potential pasture growth during the next wet season. From May 2002, however, estimates of available forage were adjusted to include the potential pasture growth that could be expected in the wet season of most $(70 \%)$ years. This change was required because in low rainfall years stocking rates calculated solely on end-of-wet season TSDM were too low e.g. $1 \mathrm{AE} / 25$ ha, to be of relevance to local practice. For both methods of estimating stocking rate, maximum upper and lower limits are set at 3 and $12 \mathrm{ha} / \mathrm{AE}$, respectively, to ensure that stocking rates are within the range deemed 'realistic' by local graziers (for more detail, see O'Reagain et al. 2008).

VAR paddocks were very lightly stocked (12.4 ha/AE) at the start of the trial due to low pasture TSDM. Stocking rates were increased to 5.7-3.9 ha/AE during the subsequent four grazing years due to good rainfall and high pasture TSDM (Table 1). In May 2002, stocking rates were substantially reduced to $8.5 \mathrm{ha} / \mathrm{AE}$ due to rapidly declining pasture TSDM (Fig. 3) and were then maintained at low levels ( 9.8 ha/AE) for the remainder of the trial period.

\section{Southern Oscillation Index - variable strategy}

In strategy 4 (SOI), stocking rates are adjusted annually in November, according to pasture TSDM measured in the late dry season and SOI phase-based climate forecasts (Stone et al. 1996) on the Queensland Climate Change Centre of Excellence 'Long paddock' website (Anon. 2008) for the coming wet season

Table 1. Stocking rates (ha/AE) in the different grazing strategies between 1997-98 and 2006-07 at the Wambiana grazing trial Stocking rates are based on actual metabolic masses $\left(\operatorname{mass}^{0.75}\right.$ ) of all animals in a treatment meaned over the grazing year. AE, animal equivalent; VAR, variable; R/Spell, rotational spelling; SOI, Southern Oscillation Index-Variable; HSR, heavy stocking rate; LSR, light stocking rate

\begin{tabular}{|c|c|c|c|c|c|c|c|c|c|c|}
\hline & \multicolumn{10}{|c|}{ Year } \\
\hline & 1997-98 & 1998-99 & 1999-00 & $2000-01$ & 2001-02 & $2002-03$ & 2003-04 & $2004-05$ & 2005-06 & 2006-07 \\
\hline VAR & 12.4 & 5.1 & 5.7 & 3.9 & 4.1 & 8.5 & 9.5 & 10.8 & 9.5 & 9.4 \\
\hline $\mathrm{R} /$ Spell & 9.1 & 7.0 & 8.0 & 7.3 & 7.0 & 6.9 & 7.9 & 9.5 & 8.6 & 9.4 \\
\hline SOI & 12.3 & 6.2 & 5.8 & 4.4 & 5.9 & 8.2 & 8.6 & 8.7 & 8.2 & 9.9 \\
\hline HSR & 6.5 & 5.0 & 5.7 & 5.2 & 4.9 & 4.8 & 4.1 & 4.0 & 5.7 & 7.4 \\
\hline LSR & 12.5 & 9.4 & 11.6 & 10.4 & 9.5 & 9.4 & 7.7 & 7.6 & 7.4 & 8.6 \\
\hline
\end{tabular}


(O'Reagain et al. 2003). Analysis of historical SOI fluctuations and Trafalgar rainfall data using Rainman (Clewett et al. 2003) indicate that the October-November index provides a useful signal of rainfall probabilities for the approaching wet season. Initially, animal numbers were adjusted to a preset stocking rate based on broad classes of pasture TSDM and SOI values in November. For example, if TSDM was greater than $3000 \mathrm{~kg} / \mathrm{ha}$ and the SOI was greater than +5 , a heavy stocking rate was applied. From November 2002 onwards, stocking rates were calculated from a feed budget derived from (i) the available forage for the rest of the dry season (as described above), and (ii) predicted wet season pasture growth expected in $70 \%$ of years with the prevailing SOI value (O'Reagain et al. 2008). The SOI strategy was initially very lightly stocked (12.3 ha/AE), due to low forage availability and the adverse SOI seasonal outlook in November 1997. Stocking rates were increased sharply to $6.2 \mathrm{ha} / \mathrm{AE}$ in October 1998 due to high pasture TSDM and positive SOI forecasts and then increased further and remained high for the next three grazing years (Table 1). In November 2001, stocking rates were cut to $\sim 6 \mathrm{ha} / \mathrm{AE}$ due to sharply declining TSDM and an indifferent SOI outlook. Stocking rates were reduced further in November 2002 and thereafter remained at low levels (8.2-9.9 ha/ AE) due to low pasture TSDM $(\sim 600 \mathrm{~kg} / \mathrm{ha})$ and negative or neutral SOI forecasts.

\section{Rotational spelling}

In strategy $5(\mathrm{R} /$ spell), rotational wet season spelling is applied in a simulated 3-paddock system. R/Spell paddocks are divided into three similar sized sections with a different section (Fig. 1) spelled annually for the full wet season (approximately November to 1 June). During the dry season, all sections within the paddock are grazed. As spelling appears to buffer the effects of higher utilisation rates on pasture condition (Ash et al. 2001), a moderate stocking rate was initially applied at 1.5 LTCC. Note that with one section closed in the wet season, the two grazed sections would be effectively grazed at a 'heavy' stocking rate. The R/Spell strategy was stocked at $\sim 7.5 \mathrm{ha} / \mathrm{AE}$ from $1997-98$ to 2002-03, but stocking rates were thereafter reduced due to the effects of fire and drought (see below). Fire, with wet season spelling, can improve pasture condition (Orr et al. 1997). Accordingly, the sections to be spelled in 2000-01 and 2001-02 were burnt following early storms in October/ November before spelling. Unfortunately, recovery from the 2001 fire was very poor, due to low rainfall and these burnt sections had to be wet-season spelled for three consecutive years (2001-02, 2002-03 and 2003-04) to encourage pasture recovery. The remaining two grazed sections in each of the $\mathrm{R} / \mathrm{Spell}$ paddocks consequently endured 3 years of heavy, wet-season grazing which, combined with below average rainfall, adversely affected pasture condition. Following consultation with the GAC, stocking rates in this treatment were reduced from 7 to $\sim 9 \mathrm{ha} / \mathrm{AE}$ in November 2003, to avoid further pasture damage.

\section{Fire management}

Fire is a common management practice in northern Australia (Bortolussi et al. 2005c). On 1 October 1999, all cattle were removed from their paddocks and weighed. The site was burnt on 11 October 1999 to remove moribund grass and control woody species. It was then spelled until 12 January 2000 to allow pasture recovery. Animals grazed together on an area adjacent to the trial site during this period, before being weighed and returned to their respective treatment paddocks.

\section{Experimental animals}

Experimental animals were initially 3/4 Brahman-cross steers from the Queensland Department of Primary Industries and Fisheries' herd at Swans Lagoon Research Station, Ayr, Queensland. However, due to a drought-induced shortage of suitable animals, since May 2004 7/8 Brahman-cross steers from the James Cook University's Fletcherview Research Station, Charters Towers have been used.

Paddocks are stocked with 11-35 steers, depending upon treatment, year, paddock area and steer liveweight. Up until the end of 2000-01 steers were $\sim 2$ year of age. With the exception of the first draft of steers that remained on the trial for 18 months (December 1997-June 1999), steers were replaced annually at the end of the grazing year in late May or early June.

From the end of May 2001 onwards, paddocks contained two similar sized cohorts of 2- and 3-year-old steers, with the older cohort being replaced by new, younger animals each year (i.e. animals remain on the trial for 2 full years). This change occurred to allow a longer period for treatment effects to emerge and because older, heavier animals could be sent directly to the meatworks to allow assessment of carcass grades and values. The single exception to this occurred in the HSR in 2005-06, which had only a single age cohort (\#3s) for that year (Fig. 5c) due to the necessity of cutting stock numbers.

\section{Animal husbandry and supplementary feeding}

All husbandry actions are based on GAC advice and follow documented industry practice (Bortolussi et al. 2005a, 2005b). Cattle were initially unsupplemented. However, following changes in local supplementation practice for steers and the advent of poorer rainfall years, a commercial dry-season urea lick (32\% urea) was provided from May 2003, and a wet season $\mathrm{P}$ supplement (14\% P, 21\% urea) was provided from December 2004 onwards. Aside from the use of lick blocks in the 2003 dry season, all lick is a dry loose-mix fed in tubs.

Steers are inoculated annually for botulism C and D, as is common for P-deficient areas (Bortolussi et al. 2005a). From May 2003 onwards, steers were also implanted annually with Compudose 400 (Elanco Animal Health, Australia) hormonal growth promotants (HGP).

Due to extremely low pasture TSDM $(<300 \mathrm{~kg} / \mathrm{ha})$ and rapidly declining animal condition, molasses and $8 \%$ urea (M8U) drought feeding was provided in open troughs to the HSR in the late dry seasons of 2003-04, 2004-05, 2005-06 and 2006-07. In November 2004 conditions were so severe steers were removed from one replicate of the HSR and fed Chloris gayana hay and M8U. Following good rains, these animals were returned to their paddock on 7 February 2005.

\section{Animal production measurements}

Cattle are weighed at the start and end of each grazing year at the end of May or early June. Animals are fasted overnight with access to water and weighed the following morning using an electronic cattle scale. Total annual liveweight gain (LWG) is calculated as the difference between fasted start- and end-weights. 
Unfasted liveweights are also recorded at the beginning and end of each grazing year and at approximate 6-week intervals during the year.

Animal condition scores are assessed at the end of the grazing year by a trained observer on a 1 to 9 scale, where 1 is extremely emaciated, 5 is 'store' condition and 9 is obese. Note: animal condition was not assessed in 1997-98 and 2002-03. Since 2003, cattle heights, measured as the vertical drop from a known height to the top of the peak of the sacrum, have also been measured at the start and end of each grazing year to index skeletal growth.

\section{Marketing}

Animals leaving the trial between 1999 and 2003 were disposed of locally or sent to other research trials. In these years, cattle agents indicated that there was little, if any, difference in value (price) per kilogram between the different strategies. From May 2004, however, animals generally went direct to the meatworks and individual carcass grades and values were recorded. Lighter and/or poorer condition animals unsuitable for the meatworks were sold at the local cattle sale. Thus, of the 2003-04 group marketed in May 2004, 94\% of cattle in the LSR went to the meatworks, $67 \%$ in the SOI and R/Spell, $47 \%$ in the VAR but only $5 \%$ in the HSR. For the 2004-05 group marketed in May 2005, $75 \%$ of steers in the HSR went to the meatworks compared to $100 \%$ in the remaining strategies. All animals from the 2005-06 and 2006-07 groups went to the meatworks. For consistency of presentation and analysis, saleyard values in 2003-04 and 2005-06 were adjusted to a nominal carcass value, based on the recorded dressing percentage of meatworks cattle.

\section{Pasture and rainfall}

Daily rainfall is measured using a network of seven rain gauges across the site. Pasture total standing dry matter (TSDM) is assessed annually at the end of the wet season (May) and in the late dry season (October) using the BOTANAL procedure
(Tothill et al. 1992). One hundred quadrat placements are made along each of two fixed transects that run the length of each paddock and traverse all soil-vegetation associations.

\section{Statistical analysis}

Statistical analyses were undertaken using the Genstat 5 Statistical package (Lawes Agricultural Trust, Rothamsted Experimental Station, UK). Liveweight gain per animal, LWG per unit area, height change and meatworks value per kg and per carcass were analysed using an analysis of variance. The experimental unit was the 'paddock' and normality assumptions were assessed using standardised normal plots of residuals. All years of data were included in the analysis to test a 'grazing strategy' by 'year' interaction for LWG variables. A 'year' was defined as the 'grazing year', as indicated earlier. The effect of grazing strategy per se on LWG, height gain and carcass value was analysed separately for each year and these results are also presented. Pair-wise comparisons between strategies were made using protected least-squares significant differences.

For years with two age cohorts, LWG per animal and height change were analysed to test for a 'grazing strategy' by 'cohort' interaction to determine if results could be pooled across cohorts. The grazing strategy by cohort interaction was not significant $(P>0.05)$ for any year, indicating there was a consistent effect of grazing strategy on the two different cohorts. Data from the two cohorts were thus pooled together for analyses.

The overall effect of grazing strategy on condition score (as measured at the end of the wet season) was assessed by analysing the number of animals in each condition score category, using a log-linear model (Poisson distribution with log link function). This was done separately for each year.

\section{Results}

\section{Rainfall}

In the first 4 years of the trial, rainfall was generally well distributed (Fig. 2). Total rainfall in these years was either

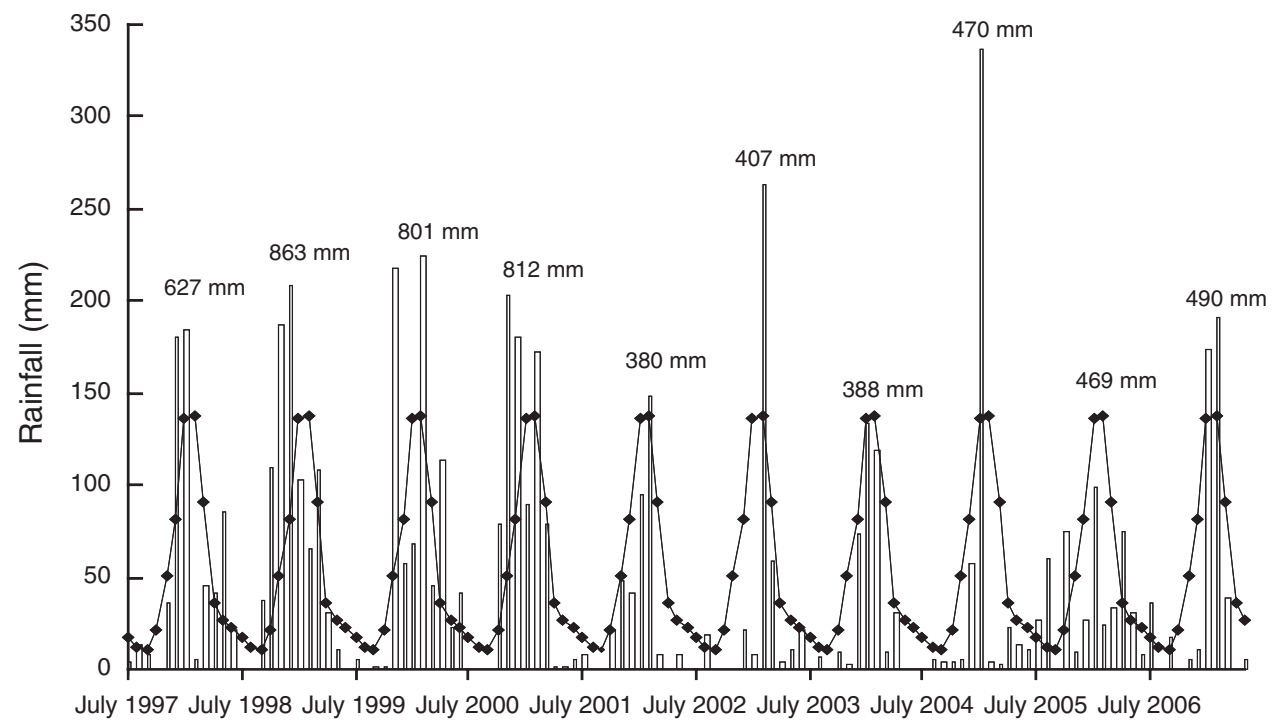

Fig. 2. Monthly rainfall (histogram) and historical long-term average monthly rainfall ( $)$ from July 1997 to May 2007 at the Wambiana grazing trail. Total annual rainfall $(\mathrm{mm})$ is indicated above each grazing year. 
average (1997-98) or markedly above average (1998-99 to 2000-01), with the latter years being in the top $20-30 \%$ of historical rainfall years. Thereafter, rainfall declined abruptly, with the period from 2001-02 to 2005-06 being within or close to the lowest $20 \%$ of rainfall years (Clewett et al. 2003). With the exception of 2005-06, when relatively good rains fell in August and October, rainfall in these later years was also poorly distributed in a few large events, giving a relatively short growing season. For example, $63 \%$ of the $407 \mathrm{~mm}$ recorded in 2002-03 fell in February 2003, with little useful rain thereafter. Rainfall in 2006-07 was also below average ( $490 \mathrm{~mm}$ ) and poorly distributed.

\section{Pasture total standing dry matter}

In all strategies, pasture TSDM changed profoundly over the course of the trial, from a high of $\sim 4500-5000 \mathrm{~kg} / \mathrm{ha}$ in $1998-99$ to average only $500 \mathrm{~kg} / \mathrm{ha}$ in 2006-07 (Fig. 3). This decline was a direct result of the effects of reduced rainfall after 2000-01 and, to a lesser extent, accumulated grazing pressure. An outbreak of armyworm (Leucania separata) in March 2003 also partially contributed to this decline. In contrast, the effects of the October 1999 fire on TSDM were relatively transient (Fig. 3) due to good follow up rains and strong pasture growth.

Relative strategy differences in pasture TSDM became more pronounced as rainfall declined (Fig. 3). As expected, TSDM tended to be highest in the LSR, at least until 2004-05, but thereafter the LSR largely converged with the more lightly stocked VAR, SOI and R/Spell strategies. Stark grazing effects were evident in later years, with HSR paddocks being almost bare (TSDM $<50 \mathrm{~kg} / \mathrm{ha}$ ) in the late dry season and having less than $10 \%$ of the TSDM in other, more lightly stocked strategies. In May 2007, pasture TSDM in the HSR was still very low $(<200 \mathrm{~kg} / \mathrm{ha})$, but there was little difference in TSDM between the other strategies (range: 460-550 kg/ha).

\section{Liveweight gain per animal}

\section{Effect of year on individual animal LWG}

Mean liveweight gain (LWG) per animal per annum varied widely between grazing years $(P<0.001)$ depending upon grazing strategy, rainfall, temperature and other environmental factors (Fig. 4a). Rainfall distribution appeared to be particularly critical in determining LWG. For example, although 2004-05 and 2005-06 had virtually the same rainfall (470 mm), LWGs in the latter year were $20-50 \mathrm{~kg}$ greater due the more even rainfall distribution. Weight gains in 2006-07 were particularly low due to poor rainfall distribution, reduced pasture availability and, in the HSR at least, an apparent decline in inherent pasture productivity.

The pattern of weight gain within the grazing year was distinctly seasonal in all strategies, being greatest between about December and May when the majority of rain generally fell i.e. the wet season (Fig. 5). However, the starting date and duration of this period of weight gain varied widely between years, in accordance with the timing and distribution of rainfall. In some dry seasons weight gain also occurred but, in most years $(\sim 60 \%)$ animals generally either only maintained or, more commonly, lost weight through this period. This was especially noticeable in heavier stocked strategies. Weight loss was sometimes severe with, for example, (unsupplemented) animals in the SOI strategy losing an average of $80 \mathrm{~kg}$ in the 2001 dry season. In other years however, significant 'dry season' weight gain did occur, as happened after unseasonable rainfall in August and September 2005, but these years were exceptional.

\section{Effect of grazing strategy on individual LWG}

When analysed across all years, the main effect of grazing strategy on LWG was significant $(P<0.001)$, but inconsistency between years also led to a significant treatment $\times$ year interaction effect $(P<0.008)$. Between-year inconsistencies were also

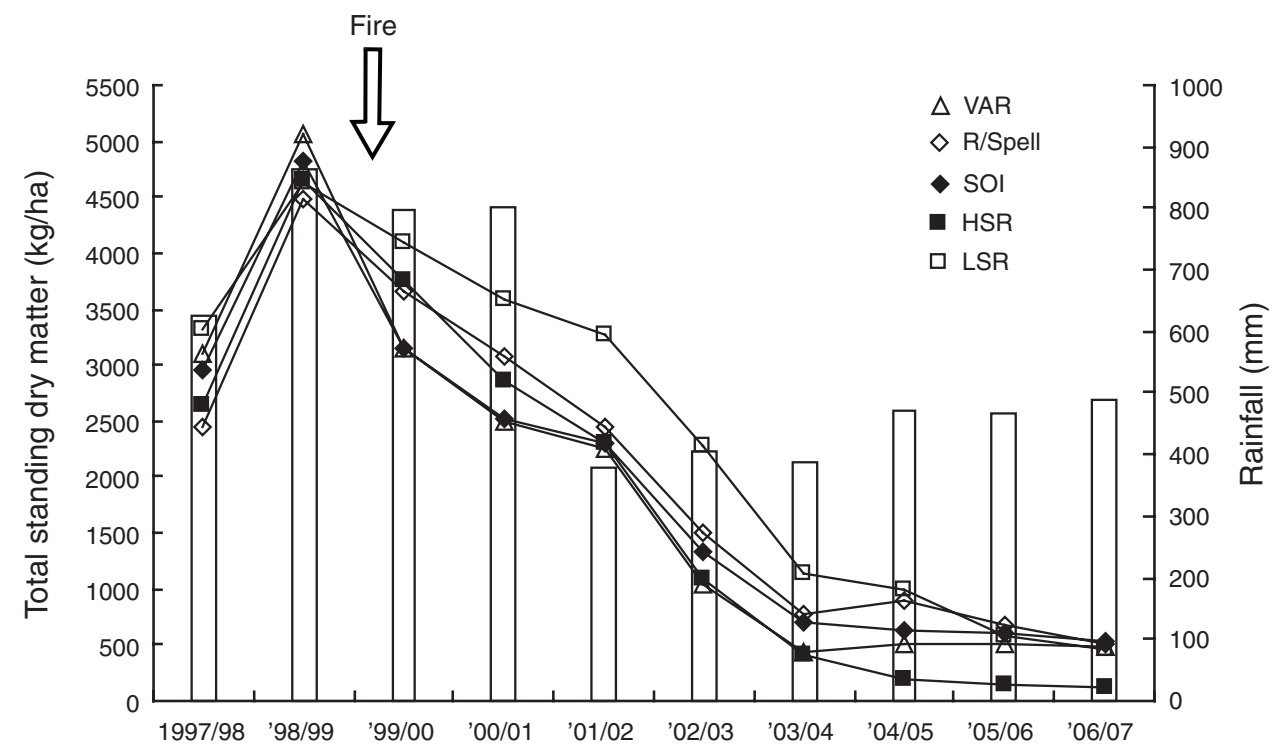

Fig. 3. Change in pasture total standing dry matter (TSDM) and annual rainfall between 1997-98 and 2006-07 under different grazing strategies at the Wambiana grazing trial for the $\operatorname{VAR}(\triangle), \mathrm{R} / \operatorname{Spell}(\diamond), \operatorname{SOI}(\diamond), \operatorname{HSR}(\square)$ and LSR ( $\square$ ) grazing strategies, with the vertical arrow marking the approximate timing of the 1999 fire. See text for treatment abbreviations. TSDM is the mean of October and May estimates for each grazing year. 

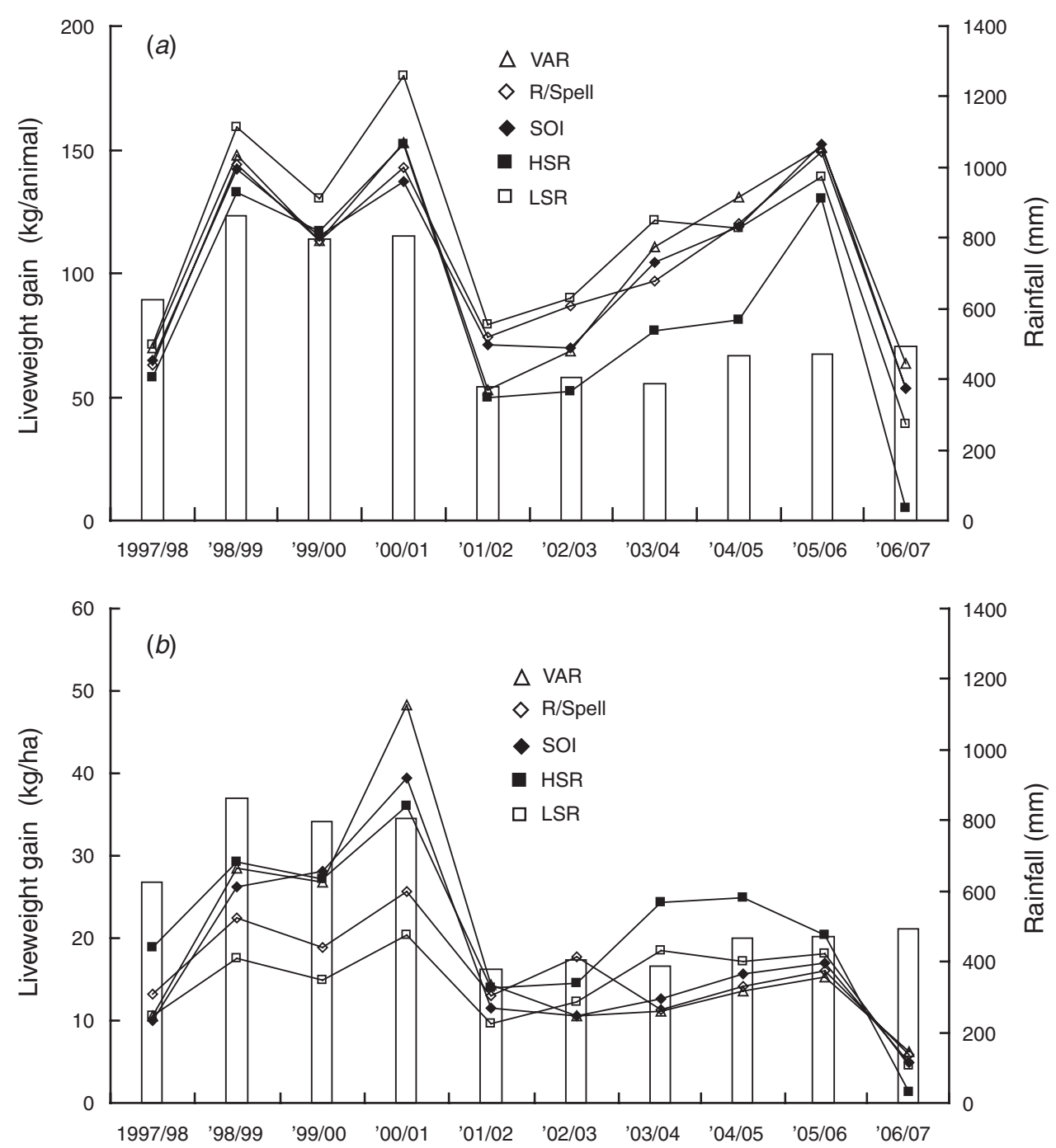

Fig. 4. Annual rainfall (histogram) and (a) liveweight gain (LWG) per animal and (b) LWG per hectare (ha) for different grazing strategies at the Wambiana grazing trial from 1997-98 to 2006-07 for the VAR $(\triangle)$, R/Spell $(\diamond)$, SOI $(\checkmark)$, HSR $(\square)$ and LSR $(\square)$. See text for treatment abbreviations.

evident when the analysis was performed for individual years (Table 2). Such between-year variability in the effect of strategy on LWG is not surprising given that rainfall and, in some cases, stocking rate (e.g. in the SOI) varied substantially between years.

'Grazing strategy' significantly $(P<0.05)$ affected LWG in 5 of the 10 years of the study. Obvious, but non-significant, differences in LWG were also apparent in most other years (Table 2). This lack of significance largely reflects the low level of replication $(n=2)$ in the trial, as well as the betweenreplicate variation in LWG that sometimes occurred.

From a practical management perspective however, grazing strategy had a clear and consistent impact upon weight gain, with mean LWG over the 10 years being highest in the LSR $(113 \mathrm{~kg})$ and lowest in the HSR $(86 \mathrm{~kg})$. The superior individual production under light stocking, relative to heavy stocking, occurred in all years irrespective of rainfall or pasture availability. Individual LWGs were thus greater in the LSR in both 1998-99 (159 kg) and 2002-03 (90 kg) which were possibly the best and poorest rainfall years of the trial, respectively, in terms of the amount and distribution of rainfall.

Mean LWG over 10 years in the VAR $(106 \mathrm{~kg})$ and SOI $(103 \mathrm{~kg})$ strategies was also markedly higher than in the HSR but within individual years was strongly dependent upon the stocking rate applied. For example, in 2000-01 individual LWG was poor in the VAR and SOI relative to the LSR, due to the heavy grazing pressure in the former strategies (Table 1). In contrast, because the SOI and VAR were very lightly stocked in later years like 2005-06 and 2006-07, individual LWGs were superior to those in the LSR (Table 2). Mean LWG in the R/Spell $(104 \mathrm{~kg})$ was similar to that in the VAR and SOI.

The effects of 'grazing strategy' on LWG were most apparent in the dry season; while steers in lightly stocked strategies generally maintained or even gained weight, those in heavier stocked strategies frequently lost weight, even with urea supplementation e.g. 2003-04 (Fig. 5). In extreme cases, M8U drought feeding was required to slow weight loss and avert 

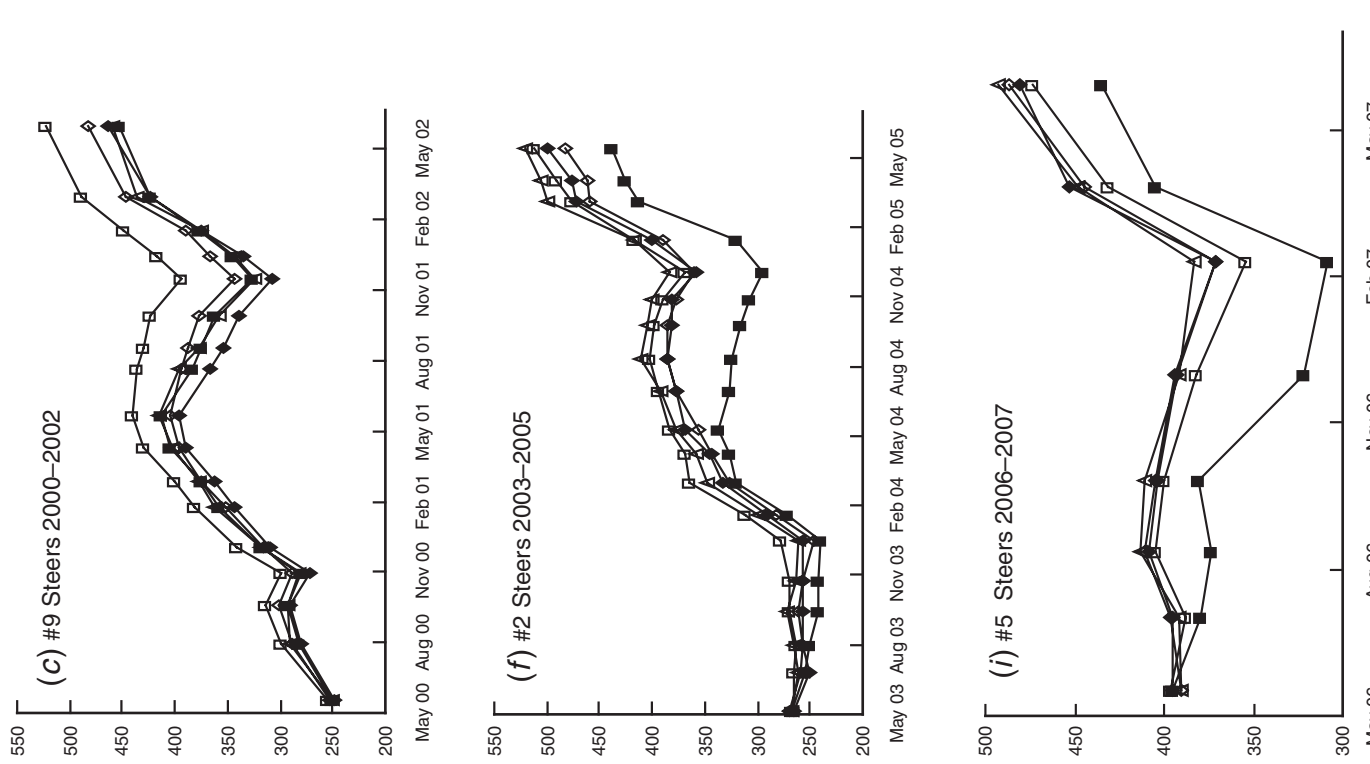

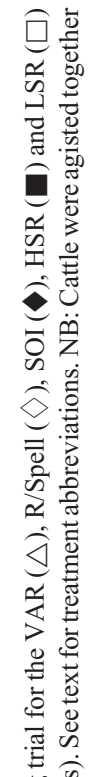
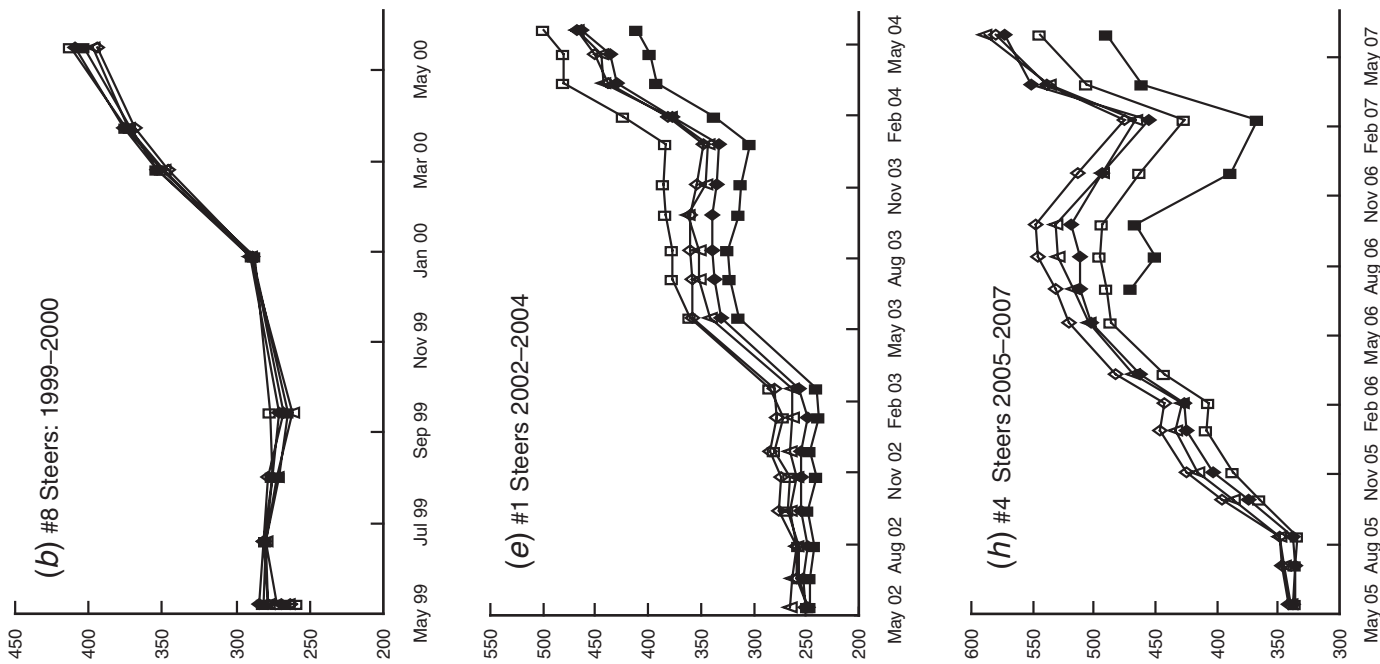

雚苋

.

3

Eี

.0

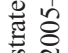

on

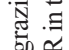

on 0

离

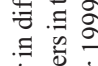

芯过

茟苍
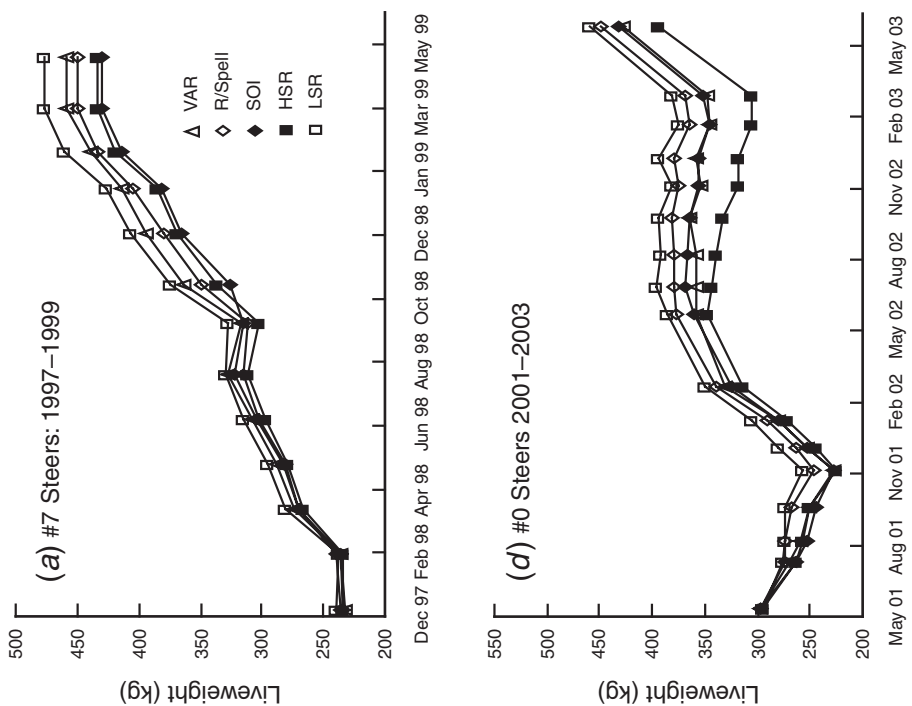

(Бу) เчБ!әмәм!า

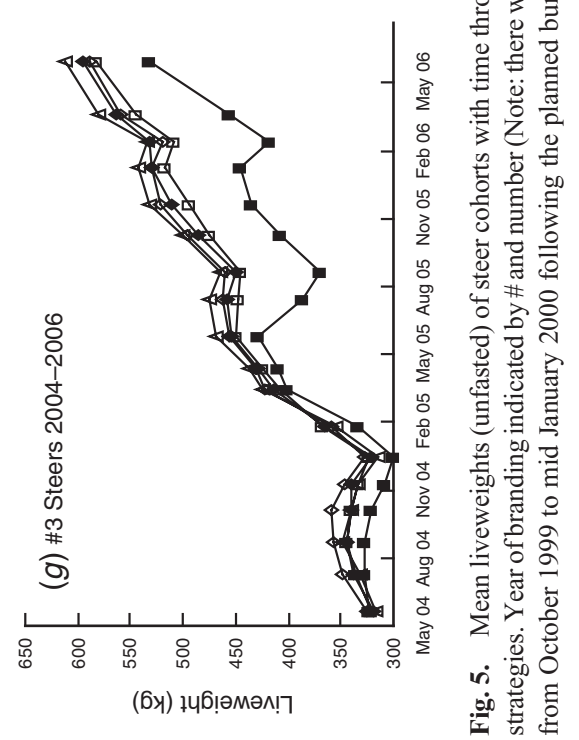


Table 2. Mean annual liveweight gain (LWG) per animal, LWG per hectare and condition score for five grazing strategies over 10 years at the Wambiana grazing trial

$F$-probabilities are for overall treatment differences in the same year; s.e.d., standard error of a difference; within a year, means for the same variable with the same letter do not differ significantly at $P=0.05$. Significance of the treatment $\times$ condition score interaction for the $\log \operatorname{linear}$ analysis of condition score is given in the bottom row. VAR, variable; R/Spell, rotational spelling; SOI, Southern Oscillation Index-Variable; HSR, heavy stocking rate; LSR, light stocking rate

\begin{tabular}{|c|c|c|c|c|c|c|c|c|c|c|}
\hline & \multicolumn{10}{|c|}{ Year } \\
\hline & $1997-98^{\mathrm{A}, \mathrm{C}}$ & 1998-99 & $1999-00^{\mathrm{B}}$ & $2000-01$ & $2001-02$ & $2002-03^{\mathrm{C}}$ & $2003-04$ & $2004-05$ & 2005-06 & 2006-07 \\
\hline \multicolumn{11}{|c|}{ Liveweight gain per animal ( $\mathrm{kg}$ ) } \\
\hline VAR & 70 & 148 & 113 & $153 \mathrm{c}$ & 51 & $68 \mathrm{ab}$ & 110 & $131 \mathrm{~b}$ & $151 \mathrm{ab}$ & $62 \mathrm{a}$ \\
\hline $\mathrm{R} / \mathrm{Spell}$ & 63 & 144 & 113 & $144 b$ & 74 & $86 b$ & 97 & $120 \mathrm{~b}$ & $149 \mathrm{ab}$ & $51 \mathrm{ab}$ \\
\hline SOI & 65 & 142 & 115 & $138 \mathrm{a}$ & 69 & $69 \mathrm{ab}$ & 104 & $119 \mathrm{~b}$ & $152 \mathrm{a}$ & $53 \mathrm{ab}$ \\
\hline HSR & 58 & 133 & 117 & $152 \mathrm{c}$ & 50 & $52 \mathrm{a}$ & 76 & $81 \mathrm{a}$ & $130 \mathrm{~b}$ & $8 \mathrm{c}$ \\
\hline LSR & 71 & 159 & 130 & $180 \mathrm{~d}$ & 79 & $90 \mathrm{~b}$ & 121 & $118 \mathrm{~b}$ & $139 \mathrm{ab}$ & $38 \mathrm{~b}$ \\
\hline$F$-prob. & 0.543 & 0.26 & 0.416 & $<0.001$ & 0.181 & 0.037 & 0.134 & 0.008 & 0.003 & 0.008 \\
\hline s.e.d. & 8.46 & 9.9 & 8.19 & 0.89 & 12.09 & 8.18 & 15.09 & 7.75 & 7.83 & 6.94 \\
\hline \multicolumn{11}{|c|}{ Liveweight gain per hectare $(\mathrm{kg} / \mathrm{ha})$} \\
\hline VAR & 10 & $28 \mathrm{a}$ & $26 \mathrm{a}$ & $48 \mathrm{a}$ & 14 & $10 \mathrm{c}$ & 11 & $13 \mathrm{c}$ & 15 & $6 a$ \\
\hline $\mathrm{R} /$ Spell & 13 & $22 b$ & $18 b$ & $25 \mathrm{c}$ & 13 & $17 \mathrm{a}$ & 11 & $14 \mathrm{c}$ & 16 & $6 \mathrm{a}$ \\
\hline SOI & 10 & $26 a b$ & $28 \mathrm{a}$ & $39 b$ & 11 & $10 \mathrm{c}$ & 12 & $15 \mathrm{bc}$ & 16 & $5 \mathrm{a}$ \\
\hline HSR & 18 & $29 \mathrm{a}$ & $27 \mathrm{a}$ & $35 b$ & 14 & $14 \mathrm{ab}$ & 24 & $24 \mathrm{a}$ & 20 & $1 b$ \\
\hline LSR & 10 & $17 \mathrm{c}$ & $14 \mathrm{~b}$ & $20 \mathrm{c}$ & 9 & $12 \mathrm{bc}$ & 18 & $17 b$ & 18 & $5 \mathrm{a}$ \\
\hline$F$-prob. & 0.055 & 0.01 & 0.004 & 0.001 & 0.338 & 0.026 & 0.116 & $<0.001$ & 0.37 & 0.056 \\
\hline s.e.d. & 2.15 & 1.72 & 1.66 & 1.93 & 2.17 & 1.41 & 4.24 & 0.81 & 2.38 & 1.14 \\
\hline \multicolumn{11}{|c|}{ Condition score (1-9) } \\
\hline VAR & - & 6.2 & 6.4 & 6.7 & 6.2 & - & 6.4 & 6.7 & 6.9 & 6.6 \\
\hline $\mathrm{R} /$ Spell & - & 6.4 & 6.4 & 6.5 & 6.6 & - & 6.5 & 6.1 & 6.9 & 6.7 \\
\hline SOI & - & 6.2 & 6.3 & 6.5 & 6.6 & - & 6.2 & 6.3 & 6.9 & 6.7 \\
\hline HSR & - & 5.9 & 6.6 & 6.9 & 6.2 & - & 5.5 & 5.6 & 7 & 6.1 \\
\hline LSR & - & 6.3 & 6.5 & 7.2 & 7 & - & 6.6 & 6.6 & 6.9 & 6.6 \\
\hline Treat. $\times$ Control & - & 0.003 & 0.456 & 0.008 & 0.001 & - & 0.001 & 0.001 & 0.989 & 0.072 \\
\hline
\end{tabular}

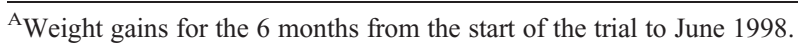

${ }^{B}$ In 1999-2000 all animals were agisted together for 15 weeks after the trial was burnt - see text for details.

${ }^{\mathrm{C}}$ Condition scores not recorded in 1997-98 and 2002-03.

mortality, as happened in the HSR for four consecutive dry seasons from 2003 to 2006. Although cattle did sometimes gain or at least maintain weight under heavy stocking in the dry season, these were exceptional years with well-distributed rainfall.

Grazing strategy appeared to have little effect on the pattern of wet season LWG in most years, with cattle appearing to perform equally well irrespective of the grazing strategy applied. Although there was some slight evidence of compensatory growth in strategies where animals had lost weight in the dry season (e.g. \# 3 steers in the HSR in 2004-05), the overall impact upon treatment differences was minimal and such animals usually finished the year $30-50 \mathrm{~kg}$ behind their lighter stocked contemporaries. After 2 years, steers from lightly stocked strategies were accordingly 60 to $100 \mathrm{~kg}$ heavier than those from the HSR (Fig. 5).

\section{Effect of treatment on condition score}

'Grazing strategy' significantly $(P<0.05)$ affected condition score (CS) in 5 of the 8 years where CS was recorded: overall, condition was markedly better in lightly stocked strategies (Table 2). Non-significant differences in CS occurred in 1999-2000 when all cattle were agisted together for 15 weeks after the fire, which probably reduced between-strategy differences in condition. Differences were again nonsignificant in 2005-06 when well-distributed rains ensured good animal condition in all strategies. Strategy differences were also non-significant $(P<0.072)$ in $2006-07$, but steers in the HSR were still half a condition score lower than those in the other, more lightly stocked strategies.

Importantly, condition score was assessed at the end of the wet season, when body condition was highest and treatment differences least pronounced. In the dry season, the differences in body condition observed in the paddock were far greater. In general, steers in lighter stocked strategies largely retained condition, whilst those in heavier stocked strategies rapidly lost condition as the dry season progressed (P. O'Reagain, pers. obs.).

\section{Effect of grazing strategy on animal height gain}

Skeletal growth, as indexed by height gain, was generally greater in lightly stocked strategies than in heavily stocked strategies, although this effect was significant $(P<0.05)$ in only 1 of 4 years (Table 3 ). For example, in 2003-04, height gain was greatest $(P<0.09)$ in lightly stocked regimes like the LSR, VAR and SOI (mean: $108 \mathrm{~mm}$ ) but least in the HSR (88 mm). Similarly, in 2004-05 gain was greatest $(P<0.05)$ in the VAR and SOI (mean: $66 \mathrm{~mm})$, least in the HSR $(45 \mathrm{~mm})$ and 
Table 3. Mean annual height gain $(\mathrm{mm})$ per animal for five grazing strategies at the Wambiana grazing trial

Data are means across both age cohorts for strategy and year. $F$-probabilities are for overall treatments differences in the same year. Values within the same column followed by the same letter do not differ significantly at $P=0.05$; VAR, variable; R/Spell, rotational spelling; SOI, Southern Oscillation Index-Variable; HSR, heavy stocking rate; LSR, light stocking rate; s.e.d., standard error of a difference

\begin{tabular}{lcccr}
\hline & \multicolumn{4}{c}{ Year } \\
& $2003-04$ & $2004-05$ & $2005-06$ & $2006-07$ \\
\hline VAR & 109 & $66 \mathrm{c}$ & 78 & 57 \\
R/Spell & 97 & $63 \mathrm{bc}$ & 59 & 69 \\
SOI & 105 & $67 \mathrm{c}$ & 60 & 50 \\
HSR & 88 & $45 \mathrm{a}$ & $38^{\mathrm{A}}$ & 45 \\
LSR & 110 & $52 \mathrm{ab}$ & 66 & 55 \\
F-prob. & 0.09 & 0.012 & $0.092^{\mathrm{A}}$ & 0.469 \\
s.e.d. & 8.93 & 6.25 & $6.35^{\mathrm{A}}$ & 12.49 \\
\hline
\end{tabular}

${ }^{\mathrm{A}}$ Analysis excludes HSR in 2005-06.

intermediate in the LSR $(52 \mathrm{~mm})$. The relatively poor gain in the LSR is not surprising given that it was the second heaviest stocked strategy that year. In 2005-06, a full strategy comparison was not possible as there was only one cohort of steers in the HSR, but differences between the remaining, relatively lightly stocked strategies were non-significant. As in previous years, height gain in 2006-07 was lowest in the HSR, but differences were non-significant.

\section{Animal production per unit area}

\section{Effect of year and treatment on gain per unit area}

Major differences $(P<0.001)$ in LWG per unit area $(\mathrm{LWG} / \mathrm{ha})$ occurred over the course of the trial with production being greatest in the early, wetter years (1998-99 to 2000-01) but dropping sharply in the relatively dry years thereafter (Table 2; Fig. $4 b$ ). In the HSR for example, LWG/ha declined from $35 \mathrm{~kg} / \mathrm{ha}$ in $2000-01$ to only $14 \mathrm{~kg} / \mathrm{ha}$ the following year. Production in 2006-07 was exceptionally poor in all strategies. This probably reflects a combination of poor rainfall distribution and a general loss of pasture vigour resulting from continuing below-average rainfall (Fig. 2). In the HSR, productivity was probably also reduced by a decline in pasture condition (O’Reagain et al. 2008).

Analysed over all years, 'strategy' had a significant $(P<0.001)$ effect on LWG/ha but, as indicated by the significance $(P<0.001)$ of the year $\times$ strategy interaction, the effect was not consistent across years. This reflects variability in rainfall and, in some strategies, changes in stocking rate. Thus, while the VAR stocked at $3.9 \mathrm{ha} / \mathrm{AE}$ in $2000-01$ produced $48 \mathrm{~kg} / \mathrm{ha}$, by $2003-04$ the stocking rate had been reduced to $\sim 10 \mathrm{ha} / \mathrm{AE}$ and LWG/ha dropped to only $11 \mathrm{~kg} / \mathrm{ha}$ (Table 2).

Significant differences between strategies occurred in most years (Table 2), with the greatest LWG/ha typically occurring in the heaviest stocked strategies (Fig. 4b). For example, in 1999-2000 LWG/ha in the HSR was almost double that in the LSR (27 v. $14 \mathrm{~kg} / \mathrm{ha})$. Although strategy effects were non-significant in 2001-02 and 2003-04, large differences in LWG/ha were still apparent between strategies (Table 2).
Table 4. Mean value per $\mathrm{kg}$ and per carcass for five grazing strategies at the Wambiana grazing trial

$F$-probabilities are for overall treatment differences in the same year. Within the same column, values followed by the same letter do not differ significantly at $P=0.05$; VAR, variable; R/Spell, rotational spelling; SOI, Southern Oscillation Index-Variable; HSR, heavy stocking rate; LSR, light stocking rate; s.e.d., standard error of a difference

\begin{tabular}{|c|c|c|c|c|}
\hline & & & & \\
\hline & 2003-04 & 2004-05 & 2005-06 & 2006-07 \\
\hline & & ue per $k g$ & & \\
\hline VAR & 2.91 & $2.96 \mathrm{a}$ & 3.30 & 2.92 \\
\hline $\mathrm{R} /$ Spell & 2.84 & $2.93 a$ & 3.28 & 2.80 \\
\hline SOI & 2.85 & $2.97 \mathrm{a}$ & 3.29 & 2.95 \\
\hline HSR & 2.94 & $2.78 \mathrm{~b}$ & 3.21 & 2.69 \\
\hline LSR & 2.84 & $2.96 \mathrm{a}$ & 3.28 & 2.83 \\
\hline$F$-prob. & 0.408 & 0.025 & 0.085 & 0.175 \\
\hline s.e.d. & 0.04 & 0.03 & 0.02 & 0.06 \\
\hline & & rcass value & & \\
\hline VAR & $593 b$ & 758 & $1037 \mathrm{a}$ & 861 \\
\hline R/Spell & $608 \mathrm{ab}$ & 696 & $1018 \mathrm{a}$ & 782 \\
\hline SOI & $605 \mathrm{ab}$ & 717 & $1025 \mathrm{a}$ & 875 \\
\hline HSR & $495 c$ & 566 & $870 \mathrm{~b}$ & 664 \\
\hline LSR & $673 a$ & 739 & 993a & 768 \\
\hline$F$-prob. & 0.022 & 0.054 & 0.038 & 0.071 \\
\hline s.e.d. & 20 & 31 & 25 & 37 \\
\hline
\end{tabular}

The lack of significance in 2003-04 is surprising but reflects the sometimes patchy distribution of storms across the trial site; in December 2003 an early storm delivered $70 \mathrm{~mm}$ to the second replicate of the HSR but only $35 \mathrm{~mm}$ fell in the first. This apparently small difference in rainfall resulted in a longer growing season in the former paddock and, consequently, a much greater LWG/ha (31 v. $17 \mathrm{~kg} / \mathrm{ha})$.

Importantly, treatment differences in LWG/ha narrowed after 2000-01 (Fig. 4b) so that, by 2005-06, production differences between the HSR and LSR were relatively minor $(20 v .18 \mathrm{~kg} / \mathrm{ha})$ and by $2006-07$ had been completely reversed ( 1 v. $5 \mathrm{~kg} / \mathrm{ha}$ ). While the initial narrowing is rainfall related, later trends suggest a possible decline in production potential under constant heavy stocking, particularly given the reduced stocking rates applied in the HSR since 2005.

\section{Market performance}

Steer market performance for the years 2003-04 to 2006-07 is presented in Table 4. In general, value per kg carcass weight was $\$ 0.10$ to $\$ 0.20$ lower for HSR steers compared to those from lightly stocked strategies like the LSR and, in these years at least, the SOI and VAR (Table 1). However, this difference in value $/ \mathrm{kg}$ was only significant $(P<0.025)$ in 2004-05 (Table 4). The single exception to this trend occurred in 2003-04 when HSR steers achieved the highest value $/ \mathrm{kg}$. This was because most (95\%) had to be marketed through the local saleyards where thinner, lighter animals were in demand for fattening. Nevertheless, these HSR steers still returned a markedly lower total value, because of their lighter weights, than animals from the other strategies.

Total carcass value across all years was from $\$ 120$ to $\$ 160$ less in the HSR compared to the other strategies, with this difference 
being significant $(P<0.05)$ in 2 out of 4 years. The higher carcass value obviously reflected the greater total bodyweight (Table 2) and value per $\mathrm{kg}$ achieved in the lighter stocked strategies like the LSR, SOI and VAR. Variation in carcass value amongst lighter stocked strategies also occurred, reflecting relatively small differences in stocking rate. For example, in 2006-07 carcass value in the LSR was about \$100 lower than in the more lightly stocked SOI and VAR.

\section{Discussion}

Animal performance, expressed in terms of both LWG per animal and per unit area, varied markedly between years over the 10-year period of the trial. Such interannual variability in production is common in the northern savannas of Australia (e.g. Fordyce et al. 1993) and reflects the inherent variation in the amount and distribution of rainfall. The seasonal pattern of LWG observed within grazing years is also well documented (Gillard 1979; Fordyce et al. 1993) and obviously reflects the marked seasonality of rainfall in the region.

Despite this variability, there were consistent trends in relative animal performance driven largely by stocking rate. In all years, lighter stocking at or about the long-term carrying capacity (LTCC) gave the best LWG per animal, irrespective of rainfall and pasture availability. Accordingly, over the 10 years of the trial LWG per animal was, on average, highest in the LSR and lowest in the HSR strategy (113v. $86 \mathrm{~kg})$. In the SOI and VAR, individual LWG was strongly dependent on stocking rate, with very good weight gains occurring in years like 2006-07 when these strategies were lightly stocked. Conversely, when these strategies were heavily stocked (e.g. 2000-01), LWG was as poor if not poorer than in the HSR (Table 2). Individual LWG in the R/Spell (mean: $104 \mathrm{~kg}$ ) was somewhat lower than in the LSR but still considerably greater than the HSR.

Animal condition and height gain (i.e. skeletal growth) were also greatest at lighter stocking rates at or about LTCC. After 2 years on the trial, steers in lighter stocked strategies thus finished 60 to $100 \mathrm{~kg}$ heavier and were taller and in better condition than those under heavier stocking (Fig. 5). These animals consequently received a higher carcass value $/ \mathrm{kg}$, which is a direct reflection of carcass quality at the meatworks in terms of weight-for-age, dentition, fat depth and buttock shape (AUSMEAT 2008). The higher value/kg, combined with superior weight, returned a markedly greater carcass value for these steers compared to those from heavily stocked paddocks.

These differences in individual animal performance obviously reflect stocking rate impacts on diet quality and availability. Generally, dietary quality was superior under lighter stocking, indicating reduced competition for higher quality pasture components (O'Reagain et al. 2008). Although pasture TSDM was initially high in all strategies, in later, drier years, intake would also have been restricted in heavily grazed paddocks by the scarcity of pasture. On some occasions in the late dry season, animals were forced to consume grass tussock bases and tree litter to compensate for the scarcity of forage. In later years, animal performance in the HSR was also probably reduced by the emerging effects of continuous heavy stocking on pasture composition and productivity (O'Reagain and Bushell 2008).
The present results largely concur with those from other studies conducted in north Queensland. On native pastures sown with Stylosanthes humilis, individual LWG was significantly $(P<0.05)$ better under light stocking compared to heavy stocking (mean: $122 v .104 \mathrm{~kg}$ ) in 5 out of 10 years (Gillard 1979). The reduced LWG under heavy stocking typically occurred due to feed shortages in drought years. Similarly, steer LWG was markedly higher under light stocking than under heavy stocking at two of three large-scale producer demonstration sites in north Queensland (Smith 2000).

In contrast to individual animal production, $\mathrm{LWG}$ per unit area (ha) was highest at stocking rates of about twice the LTCC but lowest when strategies were stocked at or near long-term carrying capacity. Accordingly, mean LWG/ha over 10 years was highest in the HSR $(21 \mathrm{~kg} / \mathrm{ha})$ and least in the R/Spell (16 kg/ha) and LSR (14 kg/ha). Mean production in the VAR (18 kg/ha) and SOI (17 kg/ha) was also lower than in the HSR, but within individual years was largely dependent upon rainfall and the stocking rate applied. These results are in general agreement with most other stocking rate trials like those conducted by Jones (2003) on sown and native pastures near Townsville.

Although production per unit area was greatest in the HSR strategy, these high stocking rates could only be maintained in drier years with drought feeding. In contrast, under constant light stocking, animals coped very well through dry years and did not require drought feeding despite only having access to dry season pasture and urea supplementation (O'Reagain et al. 2008). In the VAR and SOI where stocking rates had been reduced in line with declining pasture availability, drought feeding was also not required. However, a short-term reduction in production initially occurred in these latter strategies during the early dry years, due to carryover effects of the heavy stocking rates applied in previous seasons on these paddocks (O'Reagain et al. 2008).

Aside from the necessity of drought feeding in the HSR, stocking rates also had to be reduced in May 2005, suggesting a decline in the long-term carrying capacity and productive potential of these paddocks. This suggestion is reinforced by the fact that HSR animal performance in 2005-06 was lower than might have been expected given the reduced stocking rate and well distributed rains. Moreover, contrary to the previous 9 years of results, the HSR in 2006-07 had the lowest LWG/ha of all strategies, despite having the highest stocking rate. Jones (1997) similarly reported that, while LWG/ha increased as stocking rate rose from 0.3 to 0.6 steers/ha on native pasture oversown with Bothriochloa pertusa, the heaviest stocking rate of 0.9 steers/ha was unsustainable. These results appear to support the contention that high stocking rates are not sustainable in a variable climate and inevitably cause a decline in carrying capacity and animal performance in the longer term. However, the relative permanence of this effect will only be confirmed in the present trial by a continuation of the strategies and another sequence of above-average rainfall years.

In contrast, in the LSR where stocking rates were maintained relatively close to the LTCC, there have been no indications of a drop in carrying capacity or productive potential, despite an extended sequence of below-average rainfall years. In the VAR and SOI, the sharp reduction in stocking rates with the decline in TSDM that occurred with the onset of the dry years also 
ensured that the productive capacity of these strategies has apparently been largely maintained. Nevertheless, the heavy grazing pressures applied immediately before, and slightly into, the dry years adversely affected pasture condition in both the VAR and SOI relative to the LSR (O'Reagain et al. 2008).

The R/Spell strategy is difficult to assess fairly, given the confounding effects of the 2001 fire and its consequences for the management of this strategy. However, evidence from this trial (O'Reagain et al. 2008), other studies (e.g. Ash et al. 2001) and extensive producer experience (e.g. Purvis 1986) suggest that wet season spelling, combined with lighter stocking, should give acceptable animal production and maintain land condition in the longer term.

The present trial has gone significantly further than previous studies (Gillard 1979; Jones 1997, 2003) in several areas. First, the paddock sizes used are much larger and have far greater spatial variability than those used previously. Accordingly, they are more representative of the scale and complexity of commercial paddocks. Importantly, replication and careful paddock design has largely controlled this complexity, preventing betweenpaddock variation swamping treatment effects. Second, the present trial was planned and implemented with the long-term input of the local grazier community. This involvement, together with the size and spatial complexity of the trial, has allowed delivery of relevant, long-term information to the cattle industry on how different grazing strategies affect animal performance in the northern savannas.

The limitations of the present work are nevertheless recognised. First, the present results are relatively short-term relative to climate cycles and rates of ecosystem change; the longer-term effects of the different strategies on land condition and cattle production are still emerging. Further, the particular sequence of rainfall years encountered possibly influenced the relative performance of the different strategies. For example, the performance of the VAR and SOI strategies might have been less satisfactory if the sequence of dry and wet years had been more disjointed, requiring greater interannual fluctuations in stocking rate. Conversely, the performance of the HSR may have been better than that observed because a greater mix of wet and dry years may be less stressful to pasture condition than the relatively long, unbroken stretch of dry years experienced.

Second, although the experimental paddocks are relatively large $(\sim 100 \mathrm{ha})$, they are still relatively small compared to commercial paddocks, which often exceed 1000 ha in size. In large paddocks, the spatial variability of resources may buffer stocking rate effects, flattening the stocking rate-animal production relationship observed in small research paddocks (Ash and Stafford-Smith 1996). However, given the marked spatial heterogeneity of the trial paddocks, it is unlikely that the relative performance of the strategies would be significantly different in large, commercial paddocks. Although the energy expenditure of animals in large paddocks would probably be higher (e.g. the greater walking distances to water), this should only influence the absolute and not the relative performance of different strategies.

Third, many properties in the region are predominantly breeding herd operations and the manner and extent to which steer growth performance translates to breeder reproductive performance is uncertain (Ash and Stafford-Smith 1996).
Conventional wisdom is that breeder performance is relatively less responsive to stocking rate, due to buffering by either the animals themselves and/or the strategic feeding of supplements (Smith 2000). However, the supposedly dampened response to stocking rate may be misleading because dynamic stocking rate thresholds may exist, beyond which mortality or reproductive rates change catastrophically (Ash and Stafford-Smith 1996). A breeder experiment in large, commercial-scale paddocks would have been desirable in the present study but was impossible given obvious logistical, financial and statistical constraints.

In principal, grazing strategies that are sustainable and give good steer performance should also improve breeder profitability through improved reproductive performance, higher weaner weights and lower cow mortality. Reduced drought feeding and supplement use would also dramatically reduce costs, with profitability improved by the price premiums obtained for larger, better condition cull females. More importantly, land condition would largely be maintained, reducing climatic and economic risk and maintaining ecosystem integrity. There are thus sound reasons to suggest that, while the present results are unlikely to be exactly replicated in large breeder paddocks, the general principles derived in terms of the relative performance of the different grazing strategies, will still hold in larger, commercial operations.

Ultimately, the definitive test of any grazing strategy is not simply total or individual animal performance but also relates to its impact on land condition and economic performance. Detailed data on these aspects will be published elsewhere but, briefly, evidence from the present trial clearly indicates that maintaining good land condition is compatible with profitability (O'Reagain and Bushell 2008).

\section{Conclusion}

While total animal production per unit area was greatest under heavy stocking, individual LWG was reduced, leading to lower carcass value. Heavy stocking also required substantial drought feeding and management intervention to survive low rainfall years and, more importantly, was not sustainable. In contrast, grazing strategies recommended to manage for climate variability (e.g. light stocking at long-term carrying capacity) gave good individual animal production, did not require drought feeding and were sustainable over 10 years. Strategies that involved adjusting stocking rates with varying forage availability and changing seasonal conditions also performed better than constant heavy stocking but obviously have a greater risk than constant light stocking and require greater management skills. The R/Spell strategy was compromised by an ill-timed fire but also preformed satisfactorily.

This study has provided important long-term empirical data on the impact of different grazing strategies on animal performance and their potential to cope with rainfall variability. These results need to be extrapolated to the breeder and enterprise level but nevertheless provide critical evidence to challenge the assumption that sustainable management is unprofitable.

\section{Acknowledgements}

We are grateful to the Lyons family of 'Wambiana' and the Wambiana Grazier Advisory Committee for their continued interest, guidance and support in 
running the trial. Peter Smith, Bob Shepherd, Geoff Fordyce, Alan Laing, Andrew Ash, Joe Rolfe, Ken Day and Greg McKeon as well as other DPI\&F and CSRIO colleagues provided valuable advice in the planning and execution of many aspects of the trial. Richard Allen, Colin Bredden, Peter Fry, Dave Smith and Peter Allen assisted with the collection of field data. Animal condition was scored by John Bushell, Dave Smith and Geoff Fordyce. Trial establishment was funded via the Australian Government's Drought Regional Initiative. Funding support for the project has been provided by Meat and Livestock Australia, the Natural Heritage Trust, the Great Barrier Reef Marine Park Authority and the CRC for Tropical Savanna Management. Previous comments by Mick Quirk, Rodd Dyer, John McIvor, Geoff Fordyce and Neil McDonald and two anonymous referees on the paper are gratefully acknowledged.

\section{References}

Anon. (2008) Rainfall probabilities based on 'Phases' of the Southern Oscillation Index. (Environmental Protection Agency, Queensland Climate Change Centre of Excellence: Brisbane) Available at http:// www.longpaddock.qld.gov.au/SeasonalClimateOutlook/ RainfallProbability/index.html [Verified 7 November 2008]

Ash AJ, Stafford-Smith DM (1996) Evaluating stocking rate impacts in rangelands: animals don't practice what we preach. The Rangeland Journal 18, 216-243. doi: 10.1071/RJ9960216

Ash A, O'Reagain PJ, McKeon G, Stafford Smith DM (2000) Managing climate variability in grazing enterprises: a case study of Dalrymple Shire, north-eastern Australia. In 'Applications of seasonal climate forecasting in agricultural and natural ecosystems: the Australian experience'. (Eds GL Hammer, N Nicholls, C Mitchell) pp. 253-270. (Kluwer Academic Publishers: Dordrecht, The Netherlands)

Ash A, Corfield JP, Ksiksi T (2001) 'The Ecograze Project: developing guidelines to better manage grazing country.' (CSIRO: Townsville, Q1d)

AUS-MEAT (2008) Guideline to over-the-hooks trading of livestock. (AUSMeat Limited: Brisbane) Available at http://www.ausmeat.com.au/ industry-standards/over-the-hooks-trading.aspx [Verified 8 November 2008]

Bortolussi G, McIvor JG, Hodgkinson JJ, Coffey SG, Holmes CR (2005a) The northern Australian beef industry, a snapshot. 2. Breeding herd performance and management. Australian Journal of Experimental Agriculture 45, 1075-1091. doi: 10.1071/EA03097

Bortolussi G, McIvor JG, Hodgkinson JJ, Coffey SG, Holmes CR (2005b) The northern Australian beef industry, a snapshot. 3. Annual liveweight gains from pasture based systems. Australian Journal of Experimental Agriculture 45, 1093-1108. doi: 10.1071/EA03098

Bortolussi G, McIvor JG, Hodgkinson JJ, Coffey SG, Holmes CR (2005c) The northern Australian beef industry, a snapshot. 4. Condition and management of natural resources. Australian Journal of Experimental Agriculture 45, 1109-1120. doi: 10.1071/EA03262

Chilcott CR, McCallum BS, Quirk MF, Paton CJ (2003) 'Grazing land management education package notes - Burdekin.' (Meat and Livestock Australia Limited: Sydney)

Clewett JF, Clarkson NM, George DA, Ooi SH, Owens DT, Partridge IJ, Simpson GB (2003) Rainman Streamflow version 4.3: a comprehensive climate and streamflow analysis package on $\mathrm{CD}$ to assess seasonal forecasts and manage climate risk. QI03040, Department of Primary Industries, Queensland.

Danckwerts JE, O'Reagain PJ, O'Connor TG (1993) Range management in a changing environment: a southern African perspective. The Rangeland Journal 15, 133-144. doi: 10.1071/RJ9930133

De Corte M, Cannon M, Barry E, Bright J, Scanlan J (1991) 'Land degradation in the Dalrymple Shire: a preliminary assessment.' (CSIRO, Davies Laboratory: Townsville, Qld)
Foran BD, Stafford-Smith DM (1991) Risk, biology and drought management strategies for cattle in central Australia. Environmental Management 33, 17-33. doi: 10.1016/S0301-4797(05)80045-3

Fordyce G, Loxton I, Holroyd R, Mayer R (1993) The performance of Brahman-Shorthorn and Sahiwal-Shorthorn cattle in the dry tropics of northern Queensland. 4. Post weaning growth and carcass traits. Australian Journal of Experimental Agriculture 33, 531-539. doi: 10.1071/EA9930531

Furnas M (2003) 'Catchments and corals: terrestrial runoff to the Great Barrier Reef.' (Australian Institute of Marine Science: Townsville, Qld)

Gardner CJ, McIvor JG, Williams J (1990) Dry tropical rangelands: solving one problem and creating another. Proceedings of the Ecological Society of Australia 16, 279-286.

Gillard P (1979) Improvement of native pastures with Townsville stylo in the dry tropics of sub-coastal northern Queensland. Australian Journal of Experimental Agriculture and Animal Husbandry 19, 325-336. doi: 10.1071/EA9790325

Isbell RF (1996) 'The Australian soil classification.' (CSIRO Publishing: Melbourne)

Johnston PW, McKeon GM, Buxton R, Coban DH, Day KA, Hall WB, Scanlan JC (2000) Managing climatic variability in Queensland's grazing lands - new approaches. In 'Applications of seasonal climate forecasting in agricultural and natural ecosystems: the Australian experience.' (Eds GL Hammer, N Nicholls, C Mitchell) pp. 197-226. (Kluwer Academic Publishers: Dordrecht, The Netherlands)

Jones R (1997) Steer gains, pasture yield and pasture composition on native pasture and native pasture oversown with Indian couch (Bothriochloa pertusa) at three stocking rates. Australian Journal of Experimental Agriculture 37, 755-765. doi: 10.1071/EA97032

Jones RJ (2003) Effects of sown grasses and stocking rates on pasture and animal production from legume-based pastures in the seasonally dry tropics. Tropical Grasslands 37, 129-150.

Landsberg RG, Ash AJ, Shepherd RK, McKeon GM (1998) Learning from history to survive in the future: management evolution on Trafalgar Station, north-east Queensland. The Rangeland Journal 20, 104-118. doi: 10.1071/RJ9980104

Lawrence DM, Graham TWG, Clark RA (1994) Sustainable grazing management: grazier's perspectives and implications for pasture management in the Maranoa region, South Queensland. Tropical Grasslands 28, 24-31.

Mann TH(1993) Flexibility - the key to managing a northern beef property. In 'Proceedings XVII international grasslands congress, Rockhampton, Australia'. pp. 1961-1964.

McIvor JG, Gardner CJ (1995) Pasture management in semi-arid tropical woodlands: effects on herbage yields and botanical composition. Australian Journal of Experimental Agriculture 35, 705-715. doi: 10.1071/EA9950705

McKeon G, Day KA, Howden SM, Mott JJ, Orr DM, Scattini WJ, Weston EJ (1990) Northern Australian savannas: management for pastoral production. Journal of Biogeography 17,355-372. doi: 10.2307/2845365

McKeon G, Ash A, Hall W, Strafford-Smith M (2000) Simulation of grazing strategies for beef production in north-east Queensland. In 'Applications of seasonal climate forecasting in agricultural and natural ecosystems, the Australian experience.' (Eds GL Hammer, N Nicholls, C Mitchell) pp. 227-252. (Kluwer Academic Publishers: Dordrecht, The Netherlands)

McKeon G, Cunningham GM, Hall WB, Henry BK, Owens JS, Stone GS, Wilcox DG (2004) Degradation and recovery episodes in Australia's rangelands: an anthology. In 'Pasture degradation and recovery in Australia's rangelands: learning from history'. (Eds G McKeon, WB Hall, BK Henry, GS Stone, IW Watson) pp. 87-172. (Queensland Department Natural Resources, Mines and Energy: Brisbane) 
O'Reagain PJ, Bushell JJ (2008) Sustainable and profitable grazing management in a highly variable environment - evidence and insights from a long term grazing trial in northern Australia. In 'Proceedings of the XXI international grassland congress - VII international rangeland congress, Hohhot, Inner Mongolia'. pp. 14-19.

O'Reagain PJ, Turner JR (1992) An evaluation of the empirical basis for grazing management recommendations for rangeland in southern Africa. Journal of the Grassland Society of Southern Africa 9, 38-49.

O'Reagain P, McKeon G, Day K, Ash A (2003) Managing for temporal variability in extensive rangelands - a perspective from northern Australia. In 'Proceedings of the VII international rangelands congress, Durban, South Africa'. (Eds N Allsopp, SJ Milton, KP Kirkman, GIH Kerley, CR Hurt, CJ Brown) pp. 799-809.

O'Reagain PJ, Brodie J, Fraser G, Bushell JJ, Holloway CH, Faithful JW, Haynes D (2005) Nutrient loss and water quality under extensive grazing in the upper Burdekin river catchment, North Queensland. Marine Pollution Bulletin 51, 37-50. doi: 10.1016/j.marpolbul. 2004.10.023

O'Reagain PJ, Bushell JJ, Holloway CH, Reid A (2007) Effects of different grazing strategies on sustainability and profitability in a variable environment. In 'Proceedings of the Northern Beef Research Update Conference'. (Eds W Pattie, B Restall) pp. 56-62. (North Australia Beef Research Council)

O'Reagain PJ, Bushell JJ, Holloway CH (2008) Testing and developing grazing principles and management guidelines for the seasonably variable tropical savannas. Meat and Livestock Australia, Final report: B.NBP.0379, Sydney.

Orr DM, Evenson CJ, Lehane JK, Bowly PS, Cowan DC (1993) Dynamics of perennial grasses with sheep grazing in Acacia aneura woodlands in south-west Queensland. Tropical Grasslands 27, 87-93.

Orr DM, Paton CJ, Lisle AT (1997) Using fire to manage species composition in Heteropogon contortus (black speargrass) pastures.1. Burning regimes. Australian Journal of Agricultural Research 48, 795-802. doi: 10.1071/ A96130

Purvis JR (1986) Nurture the land: my philosophies of pastoral management in central Australia. Australian Rangeland Journal 8, 110-117. doi: 10.1071/RJ9860110
Roe R, Allen GH (1993) Studies on the Mitchell grass association in southwestern Queensland. 3. Pasture and wool production under different rates of stocking and continuous or rotational grazing. The Rangeland Journal 15, 302-319. doi: 10.1071/RJ9930302

Scattini WJ (1973) A model for beef cattle production from rangeland and sown pasture in south-eastern Queensland, Australia. PhD thesis, University of California, USA.

Shaw NH, t'Mannetjie L (1970) Studies on a spear grass pasture in central coastal Queensland - the effect of fertilizer, stocking rate and oversowing with Stylothanthes humilis on beef production and botanical composition. Tropical Grasslands 4, 43-56.

Smith D (2000) 'Northern stocking rate demonstration.' (Queensland Department of Primary Industries and Fisheries: Brisbane)

Stockwell TGH, Smith PC, Stafford Smith DM, Hirst DJ (1991) Sustaining productive pastures in the tropics.9. Managing cattle. Tropical Grasslands 25, 137-144.

Stone RC, Hammer GL, Marcussen T (1996) Prediction of global rainfall probabilities using phases of the Southern Oscillation Index. Nature 384, 252-255. doi: $10.1038 / 384252 \mathrm{a} 0$

Tothill JC, Gillies C (1992) 'The pasture lands of northern Australia. Their condition, productivity and sustainability.' (Tropical Grassland Society of Australia: Brisbane)

Tothill JC, Hargreaves JNG, Jones RM, McDonald CK (1992) 'BOTANEL a comprehensive sampling and computing procedure for estimating pasture yield and composition 1. Field sampling.' (CSIRO: Brisbane)

Wilson AD, Harrington GN (1984) Grazing ecology and animal production. In 'Management of Australia's rangelands'. (Eds GN Harrington, AD Wilson, MD Young) pp. 63-77. (CSIRO: Melbourne)

Winks L, Lamberth FC, Moir KW, Pepper PM (1974) Effect of stocking rate and fertilizer on the performance of steers grazing a Townsville stylobased pasture in north Queensland. Australian Journal of Experimental Agriculture 14, 146-154. doi: 10.1071/EA9740146

Manuscript received 27 June 2007, accepted 27 August 2008 